\title{
PROFIL KEMAMPUAN BAHASA INGGRIS MAHASISWA \\ STKIP PGRI SIDOARJO BERDASARKAN GAYA BELAJAR
}

\author{
Endang Wahju Andjariani \\ PGSD STKIP STKIP PGRI Sidoarjo, \\ endang.wahju1818@gmail.com \\ Eni Nurhayati \\ PGSD STKIP STKIP PGRI Sidoarjo, \\ eni_nurhayati23@yahoo.com \\ Eka Nurmala Sari Agustina \\ Pendidikan Matematika STKIP STKIP PGRI Sidoarjo, \\ eka.agustina.15@gmail.com \\ Siti Nuriyatin \\ Pendidikan Matematika STKIP STKIP PGRI Sidoarjo, \\ sitinuriyatin@gmail.com
}

\begin{abstract}
Abstrak
Gaya belajar setiap orang dapat menjadi salah satu faktor orang tersebut mempunyai kemampuan pemahaman yang berbeda-beda terhadap suatu informasi. Salah satunya kemampuan seseorang dalam mempelajari bahasa inggris. Akibatnya, kemampuan bahasa inggris setiap orang bisa berbedabeda. Penelitian ini bertujuan untuk menggambarkan kemampuan bahasa inggris yang menonjol berdasarkan gaya belajarnya terutama mahasiswa matematika. Responden penelitian adalah 62 mahasiswa jurusan matematika yang diinstruksikan menjawab angket gaya belajar dan TOEP. Hasil angket gaya menunjukkan terdapat tujuh kelompok gaya belajar mahasiswa yaitu gaya belajar auditori, kinestetik, visual, auditori-kinestetik, auditori-visual, kinestetik-visual, dan auditori-kinestetik, visual yang semuanya lebih dominan mempunyai kemampuan listening lebih dominan dari pada kemampuan bahasa inggris yang lain.
\end{abstract}

Kata kunci: kemampuan bahasa inggris, gaya belajar

\begin{abstract}
Learning style of everyone can be a factor to the people to have different understanding competency about information. One of this is English and it can be different for everyone. The goal of this research was to describe English competency of 62 mathematical students by their learning style using questioner of learning style and TOEP. The result shown that there were seven type of learning style: auditory, kinesthetic, visual, auditorykinesthetic, auditory-visual, kinesthetic-visual, and auditory-kinestheticvisual that all of them have good listening competency than another.
\end{abstract}

Keywords: learning style, English competency

\section{PENDAHULUAN}

Keahlian dalam berbahasa Inggris

bukanlah merupakan sesuatu hal yang

mudah dicapai. Namun kemampuan ini dituntut untuk dimiliki oleh setiap orang. Reddy (2016) juga mengemukakan bahwa kemampuan berbahasa Inggris sangat 
penting bagi setiap lulusan perguruan tinggi. Dalam mempelajari bahasa banyak faktor yang mempengaruhi. Faktor-faktor tersebut meliputi usia, jenis kelamin, motivasi, kecerdasan, level latar belakang, strategi belajar, dan gaya belajar (Sharp, 2004; Razawi, 2011). Dari uraian tersebut menunjukkan bahwa gaya belajar merupakan salah satu faktor yeng mempengaruhi hasil kemampuan bahasa inggris seseorang termasuk mahasiswa.

Menurut Gunawan (2014) gaya belajar adalah cara setiap individu dalam berpikir, memproses, memahamai informasimelalui cara dan kesenangan yang berbeda-beda. Setiap individu mempunyai gaya belajar yang beragam. Terdapat tiga jenis gaya belajar yaitu gaya belajar visual, gaya belajar auditori, dan gaya belajar kinestetik (Gilakjani, 2012). Setiap individu memungkinkan mempunyai ketiga jenis gaya belajar, namun hanya beberapa saja yang menonjol dari ketiga jenis gaya belajar tersebut.

Gaya belajar visual yang dimiliki tiaptiap individu menurut DePorter dan Hernacki (2015) memiliki ciri-ciri sebagai berikut : a) teliti akan detail; b) teratur serta rapi; c) terbiasa berbicara dengan cepat; d) pengatur jangka panjang sekaligus perencana yang handal; e) Dapat mengeja kata-kata dengan baik serta dapat melihat kata-kata sebenarnya dalam pikirannya. maupun presentasi; f) peduli akan penampilannya, soal pakaian ataupun saat presentasi; g) Mudah mengingat bentuk pesan asosiasi visual; h) Lebih mudah untuk mengingat apa saja yang dilihat daripada didengar; i) Sulit untuk mengingat perintah secara verbal, kecuali ditulis dan seringkali diulang-ulang; j) tidak mudah terganggu oleh kebisingan; k) Memilih untuk membaca daripada dibacakan; 1) Tekun dan cepat dalam membaca; m) dalam keadaan rapat atau menerima telepon, lebih suka mencoretcoret tanpa arti;

n) berpandangan dan bertujuan secara menyeluruh dan berwaspada hingga merasa yakin dalam suatu proyek atau permasalahan; o) saat menjawab pertanyaan sering menjawab secara singkat ya atau tidak; p) Mudah lupa ketika menyampaikan pesan verbal pada orang lain; q) Cenderung memilih seni daripada musik; r) Memilih berdemonstrasi daripada pidato; s) saat memperhatikan, mudah hilang konsentrasi; t) tidak pandai memilih kata-kata, tetapi dengan jelas mengetahui apa yg harus dikatakan.

Sedangkan ciri-ciri individu dengan gaya belajar auditori meliputi a) Berbicara pada diri sendiri saat bekerja; b) Mudah terganggu oleh keributan; c) Menggerakkan bibir mereka dan 
mengucapkan tulisan dibuku ketika membaca; d) mudah menirukan dan mengulang warna suara, nada, irama ; e) lebih suka mendengarkan dan membaca dengan keras; f) Memiliki irama yang terpola dalam berbicara ; g) pandai dalam bercerita namun sulit dalam menulis; $h$ ) memfavoritkan musik daripada aktivitas seni; i) sangat fasih dalam berbicara; j) memilih untuk banyak bicara, senang menjelaskan persoalan dengan panjang lebar, dan senang berdiskusi; k) memiliki cara belajar dengan mengingat dan mendengarkan hasil diskusi daripada apa yang dilihat; 1) daripada menulis, lebih mudah mengeja dengan suara keras; m) sulit melakukan aktivitas visual seperti memotong bagian-bagian hingga sesuai satu dengan lainnya; n) menyukai humor atau candaan daripada baca komik.

Individu dengan gaya belajar kinestetik mempunyai Ciri-ciri sebagai berikut a) sering merespon perkataan fisik; b) perlahan-lahan dalam berbicara; c) ketika berbicara mendekati lawan bicara; d) menyentuh fisik lawan bicara untuk mendapat atensi; e) memiliki otot-otot yang kuat dan besar; f) sering bergaul dan berorientasi dengan fisik; g) mudah hafal cara melihat dan berjalan; h) mudah belajar dengan praktek dan memanipulasi; i) sering memberikan isyarat tubuh; j) ketika membaca sering menggunakan jari sebagai penunjuk k) sulit mengingat aspek-aspek geografi, kecuali pernah mengunjungi tempat tersebut; 1) sulit diam apalagi duduk dalam waktu yang panjang; m) senang akan buku yang mengutamakan plot dan ditunjukkan oleh gerakan tubuh ketika sedang membaca; n) memilih pilihan kata yang mengandung aksi; o) sering berkeinginan untuk melakukan sesuatu; p) senang akan permainan yang menguras waktu; q) memiliki tulisan yang kurang bagus.

Dalam dunia pendidikan, seorang mahasiswa tidak hanya belajar secara mandiri tetapi juga belajar secara bersamasama dengan didampingi oleh pendidik (dosen). Namun dalam pembelajaran, seorang pendidik tidak selalu mengetahui gaya belajar yang dimiliki oleh setiap mahasiswa. Sehingga penggunaan metode belajar yang sama diberikan untuk setiap mahasiswa. Padahal Dag \& Gecer (2009) mengatakan bahwa seseorang akan mengetahui kelebihan dan kelemamahan cara menerima informasi ketika mengetahui gaya belajarnya. Hal ini berakibat pada keberhasilan pembelajaran secara klasikal. Beberapa mahasiswa dengan gaya belajar yang sesuai dengan metode yang digunakan akan cenderung memperolah hasil yang lebih baik, begitu pula dalam belajar berbahasa inggris.

Dalam belajar bahasa Inggris, terutama tes kemampuan bahasa inggris meliputi 4 
kemampuan yang dinilai yaitu reading (membaca), listening (mendengarkan), writing (menulis), dan speaking (berbicara) (Bachman dan Palmer, dalam Sims, 2015). Menurut Sims (2015) listening adalah kemampuan yang melibatkan pendengaran dalam menerima informasi; reading adalah kemampuan membaca dan menganalisis suatu kalimat atau paragraf yang berisikan beragam informasi yang didalamnya terkandung ide pokok paragraf atau kalimat serta penarikan kesimpulan pada suatu artikel. Sedangkan structure merupakan kemampuan yang mengharuskan seseorang untuk sering berlatih dan mencoba contoh soal-soal tes dengan tujuan agar lebih cepat memahami susunan kalimat sesuai kaidah-kaidah bahasa inggris. Salah satu tes yang dilakukan perguruan tinggi untuk mengukur kemampuan bahasa Inggris mahasiswa adalah Test of English Profeciency (TOEP). Tes ini mengukur tiga kemampuan yaitu reading, listening, dan writing.

Beberapa penelitian menunjukkan hubungan positif antara gaya belajar dan kemampuan bahasa Inggris (Honayapto \& Herlina, 2017; Phantharakphong, 2012). Keterkaitan gaya belajar dan kemampuan bahas inggris ini juga disampaikan oleh Kamaruddin \& Mohamad (2011) bahwa The visual styles is the most dominant style possessed by the students and they were likely to learn with graphic, chart and writing to get better understanding and memorizing what they had learned. Berdasarkan beberapa pendapat tersebut menunjukkan adanya dugaan keterkaitan gaya belajar visual dengan kemampuan reading, gaya belajar auditori dengan kemampuan listening, dan gaya belajar kisnestetik dengan kemampuan structure.

\section{METODE PENELITIAN}

Sebanyak 62 mahasiswa menjadi responden dalam penelitian ini dengan memberikan angket gaya belajar dan tes TOEP untuk melihat kemampuan bahasa inggris mahasiswa. Peneliti melakukan analisis data untuk melihat keterkaitan kemampuan bahasa inggris mahasiswa dengan gaya belajar secara kualitatif, setelah mendapatkan data gaya belajar dan kemampuan bahasa inggris mahasiswa.

\section{HASIL DAN PEMBAHASAN}

Berdasarkan data gaya belajar yang telah didapatkan diperoleh data persentase gaya belajar yang menonjol dari semua subjek penelitian (mahasiswa) sebagai berikut.

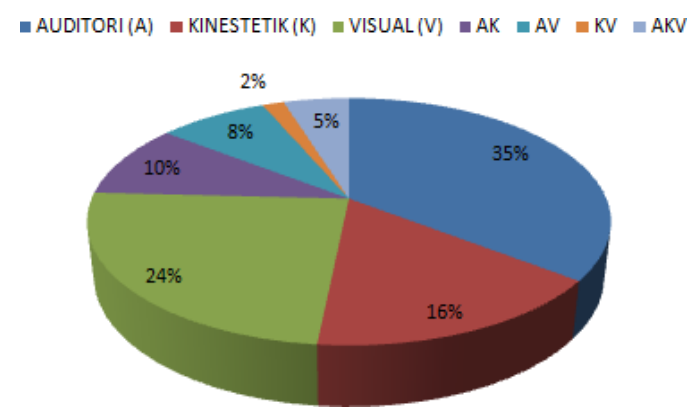


terdapat 7 kelompok gaya belajar yang paling menonjol, yaitu auditori, kinestetik, visual, auditori-kinestetik, auditori-visual, kinestetikvisual, auditori-kinestetikvisual. Dari ketujuh kelompok tersebut, gaya belajar yang paling dominan dari 62 mahasiswa adalah Auditori yang ditunjukkan dengan persentase $35 \%$.

Selain data gaya belajar, terdapat pula data kemampuan bahasa inggris yang menonjol yang dapat dilihat pada gambar berikut.

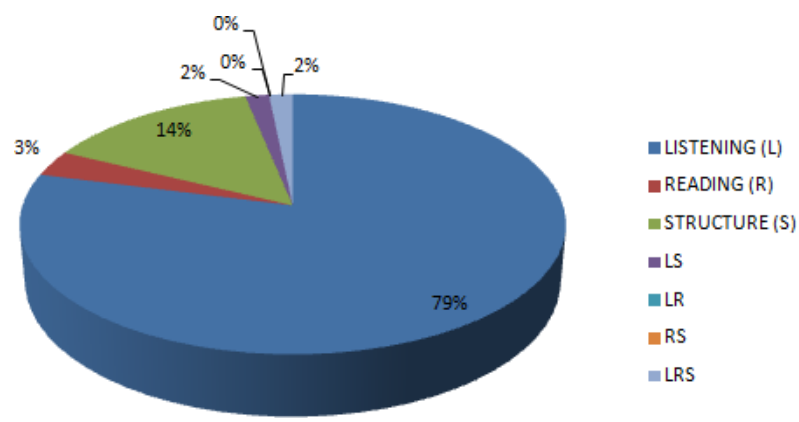

Gambar 2. Persentase Kemenonjolan Kemampuan Bahasa Inggris

Berdasarkan Gambar 2, terlihat bahwa terdapat 5 jenis kemampuan bahasa inggris yang menonjol, yaitu kemampuan listening yang paling dominan ditunjukkan dengan nilai persentase $79 \%$, kemampuan structure, kemampuan reading, kemampuan listening-reading, dan kemampuan listening-reading-structure. Tidak terdapat mahasiswa yang mempunyai kemampuan listeningstructure maupun kemampuan readingstructure.

Selanjutnya dari data gaya belajaryang menonjol dan kemampuan bahasa inggris yang menonjol, diperoleh gambaran data sebagai berikut.

\section{Kemampuan Bahasa Inggris} Mahasiswa dengan Gaya Belajar Auditori.

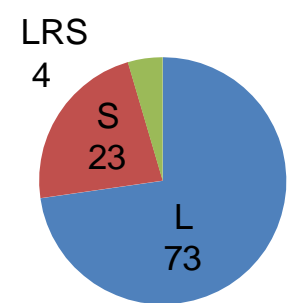

\section{Gambar 3. Diagram Kemampuan Bahasa Inggris Mahasiswa dengan Gaya Belajar Auditori}

Berdasarkan Gambar 3, terlihat bahwa kemampuan bahasa inggris yang menonjol untuk mahasiswa dengan gaya belajar Auditori adalah kemampuan listening yang dicapai oleh 73\% mahasiswa dari 22 mahasiswa dengan gaya belajar Auditori. Selain itu, terdapat $23 \%$ mahasiswa bergaya belajar Auditori lebih cenderung mempunyai kemampuan structure dan terdapat $4 \%$ mahasiswa bergaya belajar Auditori tidak dominan pada salah satu kemampuan bahasa inggrisnya. Dengan demikian, untuk mahasiswa bergaya belajar Auditori lebih cenderung mempunyai kemampuan listening dibandingkan kemampuan bahasa inggris yang lain. 
2 Kemampuan Bahasa Inggris Mahasiswa dengan Gaya Belajar Kinestetik.

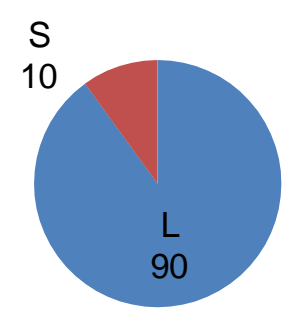

\section{Gambar 4. Diagram Kemampuan Bahasa Inggris Mahasiswa dengan Gaya Belajar Kinestetik}

Berdasarkan Gambar 4, terlihat bahwa kemampuan bahasa inggris yang menonjol untuk mahasiswa dengan gaya belajar Kinestetik adalah kemampuan listening yang dicapai oleh 90\% mahasiswa dari 10 mahasiswa dengan gaya belajar Kinestetik. Selain itu, terdapat $10 \%$ mahasiswa bergaya belajar Kinestetik lebih cenderung mempunyai kemampuan structure. Dengan demikian, untuk mahasiswa bergaya belajar Kinestetik lebih cenderung mempunyai kemampuan listening dibandingkan kemampuan bahasa inggris yang lain.
3. Kemampuan Bahasa Inggris Mahasiswa dengan Gaya Belajar Visual.

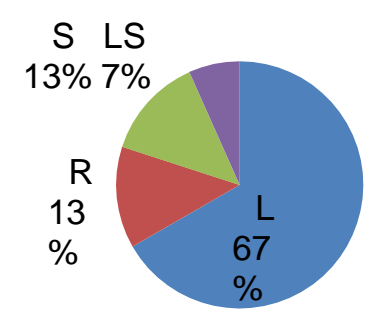

\section{Gambar 5. Diagram Kemampuan Bahasa Inggris Mahasiswa dengan Gaya Belajar Visual}

Berdasarkan Gambar 5, terlihat bahwa kemampuan bahasa inggris yang menonjol untuk mahasiswa dengan gaya belajar Kinestetik adalah kemampuan listening yang dicapai oleh 67\% mahasiswa dari 15 mahasiswa dengan gaya belajar Visual. Selain itu, terdapat $13 \%$ mahasiswa bergaya belajar Visual lebih cenderung mempunyai kemampuan reading, 13\% mahasiswa bergaya belajar Visual lebih cenderung mempunyai kemampuan structure, dan $7 \%$ mahasiswa bergaya belajar Visual lebih cenderung mempunyai kemampuan readingstructure. Dengan demikian, untuk mahasiswa bergaya belajar Visual lebih cenderung mempunyai kemampuan listening dibandingkan kemampuan bahasa inggris yang lain. 
4. Kemampuan Bahasa Inggris Mahasiswa dengan Gaya Belajar Auditori-Kinestetik.

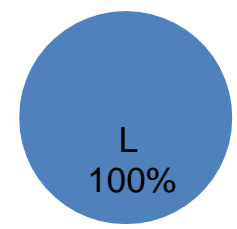

Gambar 6. Diagram Kemampuan Bahasa Inggris Mahasiswa dengan Gaya Belajar Auditori-Kinestetik

Berdasarkan Gambar 6, terlihat bahwa kemampuan bahasa inggris yang menonjol untuk mahasiswa dengan gaya belajar Auditori-Kinestetik adalah kemampuan listening yang dicapai oleh 100\% mahasiswa dari 6 mahasiswa dengan gaya belajar AuditoriKinestetik. Dengan demikian, untuk mahasiswa bergaya belajar AuditoriKinestetik lebih cenderung mempunyai kemampuan listening dibandingkan kemampuan bahasa inggris yang lain.

\section{Kemampuan Bahasa Inggris} Mahasiswa dengan Gaya Belajar Auditori-Visual.

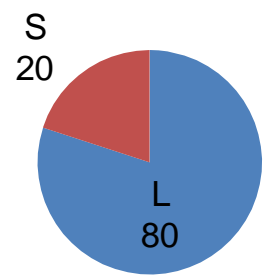

Gambar 7. Diagram Kemampuan Bahasa Inggris Mahasiswa dengan Gaya Belajar Auditori-Visual

Berdasarkan Gambar 7, terlihat bahwa kemampuan bahasa inggris yang menonjol untuk mahasiswa dengan gaya belajar Auditori-Visual adalah kemampuan listening yang dicapai oleh $80 \%$ mahasiswa dari 5 mahasiswa dengan gaya belajar Auditori-Visual. Selain itu, terdapat 20\% mahasiswa bergaya belajar Auditori-Visual lebih cenderung mempunyai kemampuan structure. Dengan demikian, untuk mahasiswa bergaya belajar AuditoriVisual lebih cenderung mempunyai kemampuan listening dibandingkan kemampuan bahasa inggris yang lain.

\section{Kemampuan Bahasa Inggris} Mahasiswa dengan Gaya Belajar Kinestetik-Visual.

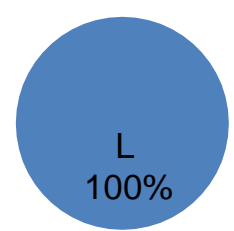

Gambar 8. Diagram Kemampuan Bahasa Inggris Mahasiswa dengan Gaya Belajar Kinestetik-Visual Berdasarkan Gambar 8, terlihat bahwa kemampuan bahasa inggris yang menonjol untuk mahasiswa dengan gaya belajar Kinestetik-Visual adalah kemampuan listening yang dicapai oleh $100 \%$ mahasiswa dari 1 mahasiswa dengan gaya belajar Kinestetik-Visual. Dengan demikian, untuk mahasiswa bergaya belajar Kinestetik-Visual lebih cenderung mempunyai kemampuan listening dibandingkan kemampuan 
bahasa inggris yang lain.

7. Kemampuan Bahasa Inggris Mahasiswa dengan Gaya Belajar Auditori-Kinestetik-Visual.

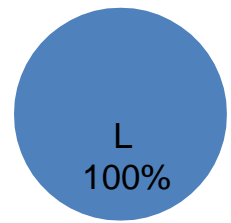

\section{Gambar 9. Diagram Kemampuan Bahasa Inggris Mahasiswa dengan Gaya Belajar Auditori-Kinestetik- Visual}

Berdasarkan Gambar 9, terlihat bahwa kemampuan bahasa inggris yang menonjol untuk mahasiswa dengan gaya belajar Auditori-Kinestetik-Visual adalah kemampuan listening yang dicapai oleh $100 \%$ mahasiswa dari 3 mahasiswa dengan gaya belajar Auditori-Kinestetik-Visual. Dengan demikian, untuk mahasiswa bergaya belajar Auditori-Kinestetik-Visual lebih cenderung mempunyai kemampuan listening dibandingkan kemampuan bahasa inggris yang lain.

\section{SIMPULAN}

Setiap mahasiswa mempunyai gaya belajar dan kemampuan bahasa inggris yang berbeda-beda. Pada penelitian ini, untuk mahasiswa matematika yang menjadi subjek penelitian lebih cenderung mempunyai gaya belajar auditori dengan kemampuan bahasa inggris yang menonjol adalah kemampuan listening.

\section{DAFTAR PUSTAKA}

Dag, F \& Gecer,A. (2009). Relations between online learning and learning styles. Journal of Procedia Social and Behavioral Sciences, 1, 862871

DePorter, Bobbi \& Hernacki, Mike.(2015). Quantum Learning (Fresh Stock). Bandung: Kaifa.

Gilakjani, P., Abbas. (2012). Visual, Auditory, Kinaesthetic Learning Styles and Their Impacts on English Language Teaching.Journal of Studies in education.2(1). 104 - 113. ISSN: $2162-6952$.

Gunawan, Imam. (2016). Pengantar Statistika Inferensial.Jakarta: Rajawali Press.

Kamaruddin, M.I. \& Mohamad, A. (2011). Kajian gaya pembelajaran dalam kalangan pelajar UTM. Journal of Educational Psychology and Counseling, 2(1), 51-77

Phantharakphong, P. (2012). English learning styles of high and low performance students of the faculty of education. ELSEVIER Journal,3390 - 3394

Reddy, M. (2016). Importance of English Language in today's World International. Journal of Academic Research, Vol.3, Issue-4(2), 179-184.

Sims, M., James. (2015). A Valid and Reliable English Proficiency Exam: A Model from a University Language Program in Taiwan. EaGLE (English as a Global Language Education) Journal.1(2).

Honayapto \& Herlina. (2017). Hubungan Sikap Dan Gaya Belajar Siswa Terhadap Kemampuan Menulis Deskriptif Bahasa Inggris.BAHTERA Jurnal Pendidikan Bahasa dan Sastra, Vol.16 No.2 , 124-138

Razawi, Nurul Amilin, et all. 2011. International Journal of Business and Social Science Vol. 2 No. 19 [Special 
Issue - October 2011] 179

STUDENTS' DIVERSE LEARNING

STYLES IN LEARNING ENGLISH

AS A SECOND LANGUAGE Nurul

Amilin Razawi 